\title{
PEMAHAMAN PERAWAT DALAM PROSES PENGAMBILAN KEPUTUSAN UNTUK MENINGKATKAN KEPROFESIONALAN PERAWAT
}

\author{
Nabila Rahmadhani \\ @rahmadhaninabila2@gmail.com
}

\begin{abstract}
There are two important things that people always face in their lives, namely problems and decision making. Making decisions is part of our daily lives both individually and as a group. Correct decision making uses a systematic approach to the nature of a problem by collecting facts and data. Decision making cannot be done like turning the palm of the hand. Based on the theory of decision making, there are several decision-making techniques that are a combination of probability theory and utility theory. The types of decision making seen from the personal who do it can be divided into two, namely: individual decisions and group decisions.
\end{abstract}

Keywords: decision making, decision making process, type of decision making

\section{Abstrak}

Ada dua hal penting yang selalu dihadapi manusia dalam hidupnya, yaitu masalah dan pengambilan keputusan. Membuat keputusan merupakan bagian dari kehidupan kita sehari-hari baik secara individu ataupun secara kelompok. Pengambilan keputusan yang tepat menggunakan suatu pendekatan yang sistematis terhadap hakekat suatu masalah dengan pengumpulan faktafakta dan data. Pengambilan keputusan tidak dapat dilakukan seperti membalik telapak tangan. Berdasarkan teori pengambilan keputusan tersebut, terdapat beberapa teknik pengembilan keputusan yang merupakan perpaduan dari teori probabilitas dan teori utilitas. Jenis-jenis pengambilan keputusan dilihat dari personal yang melakukan-nya dapat dibagi kepada dua, yaitu: keputusan individual dan keputusan kelompok.

Kata kunci: pengambilan keputusan, proses penambilan keputusan, jenis pengambilan keputusan 


\section{Latar belakang}

Hubungan perawat klien adalah dasar dari praktik keperawatan yang berfokus pada pasien (patient centered care). Keterlibatan pasien merupakan inti dari proses keperawatan, sehingga partisipasi pasien dalam proses keperawatan menjadi penting dalam penentuan kualitas dan efektifitas dalam pelayanan asuhan keperawatan. Membina hubungan ini didasarkan pada hubungan yang percaya, menghormati dan hubungan profesianal dengan mengedepankan nilai etik dan disiplin profesi. Selama praktek, profesional keperawatan menghadapi sejumlah situasi yang berbeda melibatkan klien dan pemenuhannya yang berbeda pula.

Ada dua hal penting yang selalu dihadapi manusia dalam hidupnya, yaitu masalah dan pengambilan keputusan. Menurut kamus bahasa, masalah adalah sesuatu yang harus diselesaikan, sedangkan keputusan adalah segala putusan yang telah ditetapkan.Setiap orang memiliki masalah yang harus diputuskan dalam hidupnya (Weiss and Weiss 2009; Pownall 2012).Kebijakan dan pengambilan keputusan adalah dua unsur yang saling berkaitan dan tidak bisa dipisahkan satu sama lain. Kebijakan adalah sesuatu yang lebih bersifat teoretis, sedangkan pengambilan keputusan lebih bersifat praktis. Tindakan pengambilan keputusan yang tidak didasarkan pada teoretis dapat mengurangi nilai keilmiahan sebuah keputusan, sedangkan kebijakan yang tidak disertai dengan pengambilan keputusan sulit akan menemukan wujudnya.
Kebijakan dan pengambilan keputusan adalah dua unsur yang saling berkaitan dan tidak bisa dipisahkan satu sama lain. Kebijakan adalah sesuatu yang lebih bersifat teoretis, sedangkan pengambilan keputusan lebih bersifat praktis. Tindakan pengambilan keputusan yang tidak didasarkan pada teoretis dapat mengurangi nilai keilmiahan sebuah keputusan, sedangkan kebijakan yang tidak disertai dengan pengambilan keputusan sulit akan menemukan wujudnya.

Pengambilan keputusan pada hakikatnya merupakan suatu proses pemilihan berbagi alternatif yang tersedia, mengevaluasi alternatif yang telah dipilih untuk kemudian di implementasikan dalam rangka mencapai tujuan organisasi. Dalam hal ini, jelas bahwa pengambilan keputusan melibatkan rangkaian kegiatan yang diawali dengan pengertian tentang tujuan keputusan yang hendak diambil, mengembangkan dan mengavaluasi keefektifan berbagai alternatif yang tersedia, memilih dan mengimplementasikan alternatif pilihan, dan pada akhirnya memonitor hasil implementasi guna meyakinkan bahwa tujuan keputusan tercapai. Rangkaian kegiatan ini menuntut rasionalitas yang tinggi dari seorang pengambil keputusan di samping komponen-komponen lain seperti rasa percaya diri, motivasi, dan keterampilan.

Setiadi (2012) menyatakan bahwa pada pengkajian keperawatan harus secara aktif menanyakan keluhan yang dialami dan perawat juga harus mendengarkan penuh dengan perhatian dan perasaan terhadap 
setiap apa yang dikatakan pasien. Pengkajian terdiri atas pengumpulan data dan perumusan kebutuhan atau masalah pasien sehingga perawat harus secara rutin menanyakan permasalahan-permasalahan yang masih dialami pasien karena data pasien yang sudah didapat pada tahap pengkajian diperlukan sebagai dasar pijakan dalam menentukan diagnosis keperawatan (Mundakir, 2006 \& Nurjannah 2005)

Untuk memperkecil kemungkinan manusia dilanda masalah yang tidak mampu diselesaikannya, manusia harus memahami dan terampil dalam mengambil keputusan guna memecahkan masalah yang dihadapi. Salah satu cara untuk mengembangkan keterampilan dalam mengambil keputusan tersebut adalah berpikir kreatif.

\section{Metode}

Metode yang di gunakan pengkaji dalam melakukan penulisan kajian ini adalah dengan melakukukan pengkajian menggunakan metode literature review. Denga metode literature review penulis mengumpulkan sumber berdasarkan dari berbagai sumber bacaan yang ada berupa, buku bacaan, jurnal, tesis maupun ebook yang berhubunga dengan prngambilan keputusan, proses pengambilan keputusan serta jenis pengambilan keputusan. Hal ini sayangat di butuhkan untuk meningkatkan wawasan perawat dalam mengambil kepoutusan yang paling tempat untuk masalah yang di hadapi pasien. Proses pengambilan keputusan di gunakan perawat untuk menentukan langkah-langkah yang harus di lakukan dalam menentukan keputusan yang akan dibuat oleh perawat.
Kajian ini juga merupakan kajian bebas dimana kajian ini bersifat bebas di mana kajian ini melakukan pengkajian dengan melakukan perbandingan anatar artikel-artikel yang telah di dapat kan yang berhubungan dengan pengambilan keputusan dalam keperawatan. Kajian ini terfokus pada model pengambilan keputusan yang sebelumnya lebih banyak diaplikasikan salam proses keperawatan dan dokumentasi keperawatan. Belum banyak tulisan yang memuat tentang proses dalam pengambilan keputusan, kebanyakan lebih banyak memfokuskan pada hasil dari studi atau output suatu kajian. Diskusi tentang penggunaan dari model pengambilan keputusan sebagai pisau analisis dan aplikasi dari model ini, dapat dikatakan masih sedikit.

\section{Hasil}

Hasil dari metode ini adalah seberapa besar pengetahuan perawat mengenai bagaimana langkah-langkah dalam melakukan pengambilan keputusan yang sesuai dengan apa yang di butuhkan oleh pasien. Dalam pengambilan keputusan ada delapan langkah yang raus di lakukan yaitu definisi masalah, pengumpulan data, analisis data, penentuan alternatif, pemilihan alternatif yang terbaik, putuskan, implementasikan dan monitor hasil, dan evaluasi. Langkah-langkah tersebut dilakukan agar pengambilan keputusan menghasilkan keputusan yang positif dan memiliki hasil yang positif pada respon yang di berikan pasien.

Pengambilan keputusan tidak dapat dilakukan seperti membalik telapak tangan. 
Hal tersebut dikarenakan keputusan tersebut pada gilirannya akan memberi dampak terhadap banyak aspek. Oleh sebab itu, untuk mendapatkan keputusan yang akurat dan penuh pertimbangan harus melalui tahapan-tahapan tertentu sehingga kemungkinan timbulnya dampak negatif dari keputusan tersebut dapat diminimalisir.

Untuk itu pengetahuan dan pemahaman perawat sangat di butuhkan untuk pengambilan keputusan karena semakin tinggi pengetahuan seorang perawat akan semakin tinggi keberhasilan perawat dalam menetukan keputusan keperawatan dan akan menjadikan perawat lebih profesional dalam melakukan tugasnya. Faktor yang mempengaruhi pengetahuan seseorang adalah Pendidikan berarti bimbingan yang diberikan seseorang kepada orang lain terhadap suatu hal agar mereka dapat memahami. Tidak dapat dipungkiri bahwa makin tinggi pendidikan seseorang semakin mudah pula mereka menerima informasi, dan pada akhirnya makin banyak pula pengetahuan yang dimilikinya.

\section{Pembahasan}

Membuat keputusan merupakan bagian dari kehidupan kita sehari-hari baik secara individu ataupun secara kelompok, terutama dalam suatu organisasi. Pengambilan keputusan mempunyai arti penting bagi maju atau mundurnya suatu organisasi. Pengambilan keputusan yang tepat akan menghasilkan suatu perubahan terhadap organisasi ke arah yang lebih baik, namun sebaliknya pengambilan keputusan yang salah akan berdampak buruk pada roda organisasi dan administrasinya.
Pengambilan keputusan merupakan bagian dari suatu peristiwa yang meliputi di agnosa, seleksi tindakan dan implementasi ( Beach \& Connolly, 2005). Definisi lain tent ang pengambilan keputusan juga dikemuka kan oleh Nigro (dalam Ridho, 2003) bahwa keputusan ialah pilihan sadar dan teliti terha dap salah satu alternatif yang memungkinka $\mathrm{n}$ dalam suatu posisi tertentu untuk merealis asikan tujuan yang diharapkan

Pengambilan keputusan yang tepat menggunakan suatu pendekatan yang sistematis terhadap hakekat suatu masalah dengan pengumpulan fakta-fakta dan data. Dalam menentukan alternatif yang matang untuk mengambil suatu tindakan yang tepat didasarkan pada kriteria tertentu atas dua atau lebih alternatif yang sesuai (George R. Terry, 2019). Pengambilan keputusan dalam penyelesaian masalah membutuhkan kemampuan yang mendasar bagi praktisi kesehatan, khususnya dalam asuhan keperawatan (Dolan, 2017). Pengambilan keputusan tidak hanya berpengaruh pada proses pengelolaan asuhan keperawatan, tetapi penting untuk meningkatkan kemampuan merencanakan perubahan. Perawat pada semua tingkatan posisi klinis harus memiliki kemampuan menyelesaikan masalah dan mengambil keputusan yang efektif, baik sebagai pelaksana/staf maupun sebagai pemimpin (Dolan, 2017; Nursalam, 2014).

Proses pengambilan keputusan yang dikembangkan para pakar sangat beragam. Proses tersebut dimulai dari yang sangat sederhana hingga yang paling rumit. Namun, para pakar sepakat bahwa secara umum 
pengambilan keputusan meliputi langkahlangkah antara lain; pemahaman terhadap masalah, formulasi masalah, pengembangan alternatif yang tersedia, penelusuran informasi terkait alternatif, seleksi alternatif yang mendekati solusi, keputusan, dan aksi/pelaksanaan keputusan. Meski dalam kenyataannya, tidak semua langkahlangkah tersebut secara berurut dilakukan. Beberapa permasalahan, terutama yang sederhana dan hampir rutin dihadapi dalam suatu organisasi/lembaga tidak membutuhkan proses pengambilan keputusan yang "njelimet" dalam memutuskannya. Di samping itu, aspek-aspek semisal proses kognitif yang melibatkan memori, fikiran, formasi konsep, sikap, kreativitas, dan solusi, turut berperan dalam pengambilan keputusan.

Proses pengambilan keputusan dalam praktik klinik keperawatan dipahami sebagai serangkaian keputusan yang dibuat oleh perawat dalam interaksinya dengan pasien mengenai jenis pengamatan yang akan dilakukan dalam situasi yang di alami klien (pengkajian keperawatan), perumusan diagnosa keperawatan, rencana tindakan keperawatan yang harus diambil, tindakan keperawatan yang akan diambil serta evaluasi (Dianan Catarina. 2009, Jan Florin. 2007, Mehee, 2014)

Pengambilan keputusan tidak dapat dilakukan seperti membalik telapak tangan. Hal tersebut dikarenakan keputusan tersebut pada gilirannya akan memberi dampak terhadap banyak aspek. Oleh sebab itu, untuk mendapatkan keputusan yang akurat dan penuh pertimbangan harus melalui tahapan-tahapan

tertentu sehingga

kemungkinan timbulnya dampak negatif dari keputusan tersebut dapat diminimalisir.

Siagian (1986) mengungkapkan delapan langkah pengambilan keputusan, yaitu: (1) definisi masalah, (2) pengumpulan data, (3) analisis data, (4) penentuan alternatif, (5) pemilihan alternatif yang terbaik, (6) putuskan, (7) implementasikan dan monitor hasil, dan (8) evaluasi.

Perumusan masalah dimulai dengan mengkaji fakta-fakta yang ada. Sering kali hal yang kedengarannya sederhana ini menjadi sumber kegagalan pengambilan keputusan yang benar. Masalah yang sering muncul dalam pengkajian fakta adalah pemimpin dan orang yang ada di sekitarnya sering membaurkan fakta dengan tafsiran tentang fakta tersebut. Sebuah perumusan yang baik mengidentifikasikan semua elemen-elemen yang relevan, elemen apa yang absen, dan elemen apa yang perlu ditambahkan.

Fase pengumpulan data/fakta meliputi kegiatan mendefinisikan masalah serta mengumpulkan masalah serta menganalisis data yang penting. Satu cara untuk meningkatkan kemampuan pengumpulan data adalah dengan mulai dulu melihat masalah yang ada secara luas dan kemudian melanjutkannya dengan menentukan sub masalah yang ada. Dalam hal ini, diperlukan kemampuan untuk membedakan antara gejala dari masalah yang sebenarnya.

Pembuatan alternatif-alternatif, kebijakan Setelah masalah dirinci dengan tepat dan tersusun baik, maka perlu 
dipikirkan cara-cara pemecahannya. Cara pemecahan ini hendaknya selalu diusahakan adanya alternatif-alternatif beserta konsekuensinya, baik positif maupun negatif. Pemilihan satu alternatif yang dianggap paling tepat untuk memecahkan masalah tertentu dilakukan atas dasar pertimbangan yang matang atau rekomendasi. Dalam pemilihan satu alternatif dibutuhkan waktu yang lama karena hal ini menentukan alternatif yang dipakai akan berhasil atau sebaliknya.

Dalam pelaksanaan keputusan berarti seorang pemimpin harus mampu menerima dampak yang positif atau negatif. Ketika menerima dampak yang negatif, pemimpin harus juga mempunyai alternatif yang lain. Pelaksanaan pengambilan keputusan sering menjadi masalah karena keputusan yang mesti ditanggapi oleh banyak orang malah ditangani oleh sedikit orang. Pemantauan dan Pengevaluasian Hasil Pelaksanaan Setelah keputusan dijalankan seharusnya pimpinan dapat mengukur dampak dari keputusan yang telah dibuat. Penilaian ulang perlu diadakan. Faktor-faktor penentu yang akan dinilai harus diputuskan sejak awal dan tidak setelah pelaksanaan berjalan. Dengan cara ini memang akan mudah terjadi debat yang hangat, namun akurasi akan lebih terjamin.

Dalam studi tentang pengambilan keputusan dikenal tiga teori yaitu: teori probabilitas, teori utilitas, dan teori permainan (Harrison, 1992: 219-252). Teori probabilitas didasarkan pada peluang hasil bila dalam periode waktu tertentu suatu kejadian diulangulang. Teori utilitas didasarkan pada seberapa besar manfaat yang diperoleh dari sebuah kejadian yang dipilih. Teori permainan digunakan apabila seorang pengambil keputusan tidak mengetahui sutiasi dan kondisi yang riil, dan biasanya digunakan dalam situasi konflik.

Berdasarkan teori pengambilan keputusan tersebut, terdapat beberapa teknik pengembilan keputusan yang merupakan perpaduan dari teori probabilitas dan teori utilitas. Pertama, teknik pengambilan keputusan expected values. Teknik ini mempertimbangkan kemungkinan munculnya kejadian dan kemungkinan hasil. Kedua, teknik pengambilan keputusan payoff tables. Teknik ini memperhitungkan alternatif kejadian yang muncul dan alternatif situasi yang menguntungkan atau tidak mengungtungkan. cahkan masalah. Ketiga, teknik pengambilan keputusan decision trees. Keputusan dilakukan dengan cara membuat anatomi sebuah pohon yang terdiri dari titik dan cabang.

Menurut Herbart A. Simon (dalam Asnawir, 2006: 215), setidaknya ada tiga tahap yang ditempuh dalam pengambilan keputusan, yaitu: (1) Tahap penyelidikan; tahap ini dilakukan dengan mempelajari lingkungan atas kondisi yang memerlukan keputusan. Pada tahap ini data mentah yang diperoleh, diolah dan diuji serta dijadikan petunjuk untuk mengetahui atau mengenal persoalan. (2) Tahap perancangan; pada tahap ini dilakukan pendaftaran, pengembangan, penganalisaan arah tindakan yang mungkin dilakukan dan (3) Tahap pemilihan; pada tahap ini dilakukan kegiatan 
pemilihan arah tindakan dari semua yang ada.

\section{JENIS-JENIS}

PENGAMBILAN

\section{KEPUTUSAN}

Jenis-jenis pengambilan keputusan dilihat dari personal yang melakukan-nya dapat dibagi kepada dua, yaitu: keputusan individual dan keputusan kelompok. Keputusan individual merupakan pengambilan keputusan yang dilakukan oleh pemimpin atau manajer secara sendiri; sedangkan keputusan kelompok adalah keputusan yang dibuat oleh sekelompok orang berdasarkan hasil musyawarah mufakat.

Pengambilan keputusan secara kelompok dapat pula dibedakan kepada beberapa bentuk yaitu: (1) sekelompok pimpinan, (2) sekelompok orang-orang bersama pimpinannya dan (3) sekelompok orang yang mempunyai kedudukan sama dan keputusan kelompok. Beberapa kebaikan dari pengambilan keputusan secara kelompok adalah: (1) keputusan dapat lebih cepat ditentukan atau diambil karena tidak perlu menunggu persetujuan dari rekan lainnya, (2) memperkecil kemungkinan terjadinya pertentangan pendapat dan (3) jika pimpinan atau manajer yang mengambil keputusan itu memiliki kemampuan yang tinggi dan berpengalaman luas dalam bidang yang akan diputuskan, maka keputusannya berkemungkinan besar tepat.

\section{Kesimpulan}

Pengambilan keputusan pada hakikatnya merupakan suatu proses pemilihan berbagi alternatif yang tersedia, mengevaluasi alternatif yang telah dipilih untuk kemudian di implementasikan dalam rangka mencapai suatu tujuan. Terdapat beberapa teknik pengembilan keputusan yang merupakan perpaduan dari teori probabilitas dan teori utilitas. Pertama, teknik pengambilan keputusan expected values, teknik pengambilan keputusan payoff tables, dan teknik pengambilan keputusan decision trees .Langkah dalam pengambilan keputusan, yaitu: definisi masalah, pengumpulan data, analisis data, penentuan alternatif, pemilihan alternatif yang terbaik, putuskan, implementasikan dan monitor hasil, dan evaluasi. Jenis-jenis pengambilan keputusan dilihat dari personal yang melakukan-nya dapat dibagi kepada dua, yaitu: keputusan individual dan keputusan kelompok.

\section{Daftar Pustaka}

Anwar. Herson. (2014). Proses Pengambilan Keputusan untuk Mengembangkan Mutu Madrasah. Jurnal Pendidikan Islam, 8(1). 37-56.

Ermi Sola. (2018). DECISION MAKING: Sebuah Telaah Awal. Jurnal Idaarah, 2(2). 208-215.

George R. Terry, L. W. R. (2019). Dasardasar manajemen (Edisi revi; B. sari Fatmawati, ed.). Jakarta: Bumi Aksara.

Latifa. Ade. (2010). Aplikasi Model Pengambilan Keputusan Dalam Perilaku Fertilitas. Jurnal Kependudukan Indonesia, 5(1). 5573.

Moordiningsih dan Faturochman. Proses Pengambilan Keputusan Dokter ( Physician Decision Making). Jurna Pisikologi, 33(2). 1-15 
Muhdi. dkk. (2017). Teknik Pengambilan

Keputusan Dalam Menentukan

Model Manajemen Pendidikan

Menengah. Jurnal Manajemen

Pendidikan , 4(2). 135-145

Nursalam. (2014). Manajemen Keperawatan

Aplikasi Keperawatan Profesional

Edisi 4 (4th ed.). Jakarta selatan:

Salemba Medika

Rohayuningsih. Heri dan Eko Handoyo.

(2015). Berfikir Kreatif Dalam

Pengambilan Keputusan. Jurnal

Forum Ilmu Sosial, 42(1). 106-113.

Sabri. Ahmad. (2013). Kebijakan Dan

Pengambilan Keputusan Dalam

Lembaga Pendidikan Islam. Jurnal

Al-Ta'lim, 1(5). 373-379.

Setiadi. 2012. Konsep dan Penulisan

Dokumentasi Asuhan Keperawatan

Teori dan Praktik. Graha Ilmu:

Yogyakarta.

Simamora, R. H. (2005). Hubungan Persepsi

Perawat Pelaksana Terhadap

Penerapan Fungsi Pengorganisasian

Yang Dilakukan Oleh Kepala

Ruangan Dengan Kinerjanya

Diruang Rawat Inap RSUD Koja

Jakarta Utara (Doctoral dissertation,

Tesis FIK UI, Tidak dipublikasikan).

Simamora, R. H. (2019). Menjadi perawat

yang: CIH'HUY. Surakarta: Kekata

Publisher. 